\title{
Vaccination against COVID-19 and SARS-COV-2 in people living with HIV
}

\author{
Fabio Cardoso ${ }^{1}$, Claudio Gleidiston Lima da Silva ${ }^{2}$, Savio Samuel Feitosa Machado ${ }^{2}$, \\ Sionara Melo Figueiredo de Carvalho ${ }^{2}$, Modesto Leite Rolim Neto 3 , Jaime Emanuel Brito Araújo ${ }^{4}$ \\ ${ }^{1}$ School of Medicine, Estacio de Sá University - UNESA, Campus Centro, Presidente Vargas, Rio de Janeiro, Brazil \\ ${ }^{2}$ School of Medicine, Federal University of Cariri - UFCA, Barbalha, Ceará, Brazil \\ ${ }^{3}$ Productivity Scholarship of the Juazeiro do Norte School of Medicine from Juazeiro do Norte - FMJ/Estacio, Juazeiro do Norte, \\ Ceará, Brazil \\ ${ }^{4}$ School of Medicine, Federal University of Campina Grande - UFCG, Cajazeiras, Paraíba, Brazil
}

HIV AIDS Rev 2022; 21, 1: 1-2

DOI: https://doi.org/10.5114/hivar.2022.112756

\begin{abstract}
Human immunodeficiency virus (HIV) and SARS-CoV-2 are almost nothing alike, but the response to the COVID-19 pandemic has much to learn from four decades of efforts against HIV and AIDS. It took decades of research on issues that are not at all associated with a coronavirus before prototype COVID-19 vaccines could be developed in a matter of months [1]. HIV-1, a member of Retroviridae virus family, and SARS-CoV-2, a coronavirus of subgenus Sarbecovirus, are positive-sense single-stranded RNA viruses. Main difference between SARS-CoV-2 and HIV-1, however, is that most individuals infected with SARS-CoV-2 shed the virus, while those with HIV-1 do not [2]. This is because SARS-CoV-2 is a slowly mutating and non-integrating virus, and the host can rely on a secondary vaccine-initiated immune response to clear SARS-CoV-2 infected cells [3]. After natural infection with SARS-CoV-2, people living with HIV have lower concentrations of anti-spike IgG and pseudo-virus neutralizing antibody titres [4]. For other immunocompromising conditions, such as solid organ transplantation, decreased immunogenicity for SARS-CoV-2, a messenger RNA vaccine has been documented, with emerging data for other conditions [5].

In contrast, HIV-1 integrates into the host genome approximately 72 hours after transmission. By the time a vaccine-initiated secondary immune response to HIV-1 develops, an irreversible infection occurs, with a latently established reservoir of infected CD4+ T cells with incorporated double-stranded proviral DNA. Therefore, for a successful HIV-1 vaccine, high levels of protective neutralizing antibod-
\end{abstract}

Address for correspondence: Modesto Leite Rolim Neto, Productivity Scholarship of the Juazeiro do Norte School of Medicine from Juazeiro do Norte - FMJ/Estacio, Juazeiro do Norte, Ceará, Brazil, e-mail: modesto.neto@ufca.edu.br

ies must be present at the time of transmission to completely prevent the infection [6]. CD4+ T cells, CD8+ T cells, and neutralizing antibodies all contribute to the control of SARSCoV-2 in outpatient and hospitalized cases of COVID-19 [2]. Furthermore, to prevent the escape of HIV-1 founder virus, a successful HIV-1 vaccine will need to induce B cell lines at several of the seven bnAb binding sites in HIV-1 Env [7]. An increased immunogenicity of vaccination compared to previous natural infection may attenuate or reverse differences in the immune response by HIV status [8].

According to a report recently released by the World Health Organization (WHO) [9] and presented at the International AIDS Society - IAS meeting [10], HIV appears to be a significant independent risk factor for COVID-19 serious or critical illness and mortality. COVID-19 results are worse in people infected with HIV. An analysis of people hospitalized with COVID-19 showed that serious illness and in-hospital death were higher in people living with HIV, regardless of factors, such as age, sex, and comorbidities. In this situation, HIV infection can lead to a more severe disease caused by SARS-CoV-2. Although, number of studies investigating the impact of COVID-19 on people living with HIV continues to grow, conclusive information about intersection of these two infectious diseases remains elusive. In this context, even though fewer infections were detected by SARS-CoV-2 IgG test among people living with HIV than among those without HIV, people with HIV had more cases of severe COVID-19. Among

Article history:

Received: 01.11.2021

Received in revised form: 12.11.2021

Accepted: 15.11.2021

Available online: 18.01.2022
International Journal of HIV-Related Problems

HIV \& AIDS

R e v i e w 
people living with HIV with previous SARS-CoV-2 infection, lower IgG concentrations and neutralizing pseudovirus antibody titers may reflect a decreased serological response to infection, and similar avidity may be driven for a similar time from infection [4]. While there is much to be learn on adaptive immune responses to SARS-CoV-2 and their relation to disease severity, immune memory, protection, and vaccines, an extraordinary amount has been realized during 2020. Large unknowns remain regarding the variable kinetics of virus loads and duration of infection as well as connections between these parameters and adaptive immunity and immunological memory. In addition, immunological memory duration and protective immunity to SARS-CoV-2 after COVID-19 and in response to COVID-19 vaccines, will be of high priority in the coming years [2]. Alternatively, an increased immunogenicity of vaccination, compared to previous natural infection, could attenuate or reverse differences in the immune response by HIV status [8]. However, we must not forget about HIV in these difficult times. We are concerned that many researchers have moved to COVID-19 and no longer continue their work on HIV and AIDS. A global and multisectoral response is paramount to put the most vulnerable people at the center of international discussion [1].

\section{Acknowledgments}

The authors would like to thank the School of Medicine Estácio/FMJ from Juazeiro do Norte (Productivity Scholarship Program).

\section{Funding}

The School of Medicine Estácio/FMJ from Juazeiro do Norte (Productivity Scholarship Program) and the Brazilian National Council for Scientific and Technological Development $(\mathrm{CNPq})$ - institution linked to the Brazilian Department of Science, Technology, and Innovation to encourage research in Brazil.

\section{References}

1. Pallarès G. Lições do HIV para a covid-19. El Pais 2021. Available from: https:/brasil.elpais.com/ciencia/2020-12-01/licoes-do-hiv-paraa-covid-19.html (Accessed: 15.10.2021).

2. Sette A, Crotty S. Adaptive immunity to SARS-CoV-2 and COVID-19. Cell 2021; 184: 861-880.

3. Haynes BF. SARS-CoV-2 and HIV-1 - a tale of two vacines. Nat Rev Immunol 2021; 21: 543-544.

4. Spinelli MA, Lynch KL, Yun C, et al. SARS-CoV-2 seroprevalence, and IgG concentration and pseudovirus neutralizing antibody titers following infection compared by HIV status: a matched case-control observational study. Lancet HIV 2021; 8: e334-e341.

5. Boyarsky BJ, Werbel WA, Avery RK, et al. Immunogenicity of a single dose of SARS-CoV-2 messenger RNA vaccine in solid organ transplant recipients. JAMA 2021; 325: 1784-1786.

6. Dryden-Peterson S, Velásquez GE, Stopka TJ, et al. Disparities in SARS-CoV-2 vaccination-to-infection risk during the COVID-19 pandemic in Massachusetts. JAMA Health Forum 2021; 2: e212666.
7. McMichael AJ, Borrow P, Tomaras GD, Goonetilleke N, Haynes BF. The immune response during acute HIV-1 infection: clues for vaccine development. Nat Rev Immunol 2010; 10: 11-23.

8. Spinelli MA. SARS-CoV-2 vaccination in people with HIV. Lancet HIV 2021; 8: E455-E456.

9. WHO Global Clinical Patform for COVID-19. Clinical features and prognostic factors of COVID-19 in pelple living with HIV hospitalized with suspected or confirmed SARS-COV-2 infection. 2021. Available from: https://apps.who.int/iris/bitstream/handle/10665/342697/WHO-2019-nCoV-Clinical-HIV-2021.1-eng. pdf (Accessed: 15.10.2021).

10. Bertagnolio S. Clinical characteristics and prognostic factors in people living with HIV hospitalized with COVID-19: findings from the WHO Global Clinical Platform. IAS 2021. Available from: https://theprogramme.ias2021.org/Abstract/Abstract/2498 (Accessed: 15.10 .2021$)$ 